\title{
Perancangan Alat Bantu Pada Pemasangan Nipple ke Manifold Block Untuk Memperbaiki Postur Kerja di PT. Yamata Machinery
}

\author{
Andira Taslim ${ }^{1}$, Rendy $^{2}$, Susanto ${ }^{3}$ \\ 1,2,3) Faculty of ENgineering, Industrial Engineering Department, President University \\ Jl. Ki Hajar Dewantara \\ Kota Jababeka, Cikarang, Bekasi - Indonesia 17550 \\ Email: andira@president.ac.id
}

\begin{abstract}
ABSTRAK
Quick Mold Change System merupakan produk auto clamping di mesin injeksi. PT. Yamata Machinery adalah agen resmi produk QMCS merk Kosmek di Indonesia. Dalam pemasangan satu set clamping ada satu proses yang menyebabkan beberapa bagian tubuh karyawan mengalami rasa sakit setelah pemasangan. Proses tersebut adalah pemasangan nipple ke manifold block. Jika permasalahan tidak segera ditangani, maka dapat mengakibatkan cidera permanen dimkemudian hari Tujuan penelitian ini untuk mengetahui penyebab rasa sakit karyawan dan mecari solusi untuk meminimalkan atau menghilangkan keluhan. Metode yang digunakan adalah RULA yang berfungsi untuk menilai postur kerja. Kemudian dilanjutkan dengan KANO yang berfungsi mengkategorikan atribut yang memberikan kepuasan pelanggan dan dikombinasikan dengan QFD yang berfungsi untuk menerjemahkan customer needs kedalam respon teknis. Hasil analisa penyebab rasa sakit disebabkan postur kerja yang mempunyai skor penilaian RULA sebesar 7 . Solusinya merubah postur kerja dari duduk membungkuk menjadi berdiri dan menggunakan alat bantu jig JXblock + meja + ragum yang ergonomi. Hasilnya nilai postur kerja menjadi 4, dari rasa sakit pada 10 bagian tubuh menjadi 1 bagian berdasarkan Nordic Questionare, Dampak lain adalah terjadi penurunan waktu pemasangan dari rata-rata 8.45 menit menjadi 2.35 menit.
\end{abstract}

Kata Kunci: Auto calmping, Mesin injeksi, Manifold block, postur kerja, customer needs, alat bantu

\section{ABSTRCT}

Quick Mold Change System is an auto clamping product in injection machines. PT. Yamata Machinery is the official agent for Kosmek brand QMCS products in Indonesia. In the installation of a clamping set there is a process that causes several parts of the employee's body to experience pain after installation. This process is the installation of the nipple into the manifold block. If the problem is not addressed immediately, it can result in permanent injury in the future. The purpose of this study was to determine the causes of employee pain and find solutions to minimize or eliminate complaints. The method used is RULA which serves to assess work posture. Then proceed with KANO which functions to categorize attributes that provide customer satisfaction and is combined with QFD which functions to translate customer needs into technical responses. The results of the analysis of the causes of pain are due to work posture which has a RULA assessment score of 7. The solution is to change the work posture from sitting bent to standing and using the ergonomic JXblock + table + vise jig. The result is the work posture score becomes 4, from pain in 10 parts of the body to 1 part based on the Nordic Questionnaire. Another impact is a decrease in the installation time from an average of 8.45 minutes to 2.35 minutes.

Keywords: Auto calmping, injection machine, Manifold block, work posture, customer needs, tools

\section{Pendahuluan}

Kinerja operator dalam melakukan suatu pekerjaan sangatlah penting. Dalam melakukan pekerjaan seorang operator dipengaruhi oleh banyak faktor seperti kondisi kerja, tempat kerja, postur kerja dan metode kerja. Faktor-faktor tersebut pada dasarnya akan mempengaruhi kenyamanan dan keselamatan kerja. 
Dalam dunia industri yang semakin lama serba otomatis, terdapat sebuah produk yaitu Quick Mold Change System (QMCS). QMCS merupakan produk auto clamping di mesin injeksi. PT. Yamata Machinery adalah agen resmi produk QMCS merk Kosmek di Indonesia. Dalam pemasangan satu set clamping ada satu proses yang menyebabkan beberapa bagian tubuh karyawan mengalami rasa sakit setelah pemasangan. Proses tersebut adalah pemasangan nipple ke manifold block. Jika permasalahan tidak segera ditangani, maka dapat mengakibatkan cidera permanen dimasa yang akan datang.

Berdasarkan kuesioner nordic, terdapat 10 bagian tubuh yang sakit dan 3 diantaranya mempunyai skala kategori sangat sakit. Selain masalah pada karyawan, waktu pemasangan nipple ke manifold membutuhkan waktu rata-rata 101.36 menit dari total waktu kerja 480 menit atau $21 \%$ dari total waktu kerja dalam sehari dengan jumlah manifold sebanyak 12 pieces. Hal ini mempengaruhi kinerja karyawan pada saat pemasangan satu set clamp di customer.

Oleh karena itu, penelitian ini dilakukan untuk mengetahui penyebab rasa sakit yang dialami karyawan dalam pemasangan nipple ke manifold block. Selain itu juga untuk mencari solusi meminimalkan atau menghilangkan keluhan sakit pada karyawan.

\section{Kajian Pustaka}

\subsection{Rapid Upper Limb Assessment (RULA) Method}

Rapid Upper Limb Assessment atau disingkat sebagai RULA adalah suatu metode untuk melakukan penilaian sikap atau postur tubuh seseorang atau pekerja yang sering melakukan pekerjaan aktivitas otot yang berulang-ulang/repetitive. Aktivitas otot yang dilakukan secara berulang-ulang dapat menyebabkan cidera. Penerapan ergonomi dilakukan untuk memberikan penilaian yang disajikan dalam skor risiko yang berupa angka satu sampai dengan tujuh. Semakin tinggi nilai skor. Maka pekerjaan tersebut memiliki resiko cidera yang semakin besar. Nilai skor rendah juga tidak memberikan jaminan pekerjaan bebas dari bahaya cidera dan juga ergonomi. Oleh karena itu, RULA diperlukan untuk mengetahui resiko pekerjaan dan segera memperbaiki postur kerja terutama untuk pekerjaan dengan resiko yang tinggi. (Lueder, 1996).

Dalam proses penialaian RULA, tahap-tahap penggunaanan metode Rapid Upper Limb Assessment adalah sebagai berikut: (McAtemey \& Corlett, 1993, McAtemey \& Corlett, 2004 )

1) Langkah 1, Langkah untuk pencacatan postur saat bekerja.

Pada Langkah ini, bagian tubuh dikelompokan menjadi 2 bagian, yaitu grup A yang terdiri dari lengan bawah, lengan atas dan pergelangan tangan, dan grup $B$ yang terdiri dari badan, leher, dan kaki.

2) Langakah ke 2, mengelompokkan nilai postur bagaian tubuh.

Pembebanan pada postur dari sistem muskuloskeletal yang ada kaitanya dengan kombinasi dari postur pada bagian tubuh akan diwakilkan pada kelompak A dan B, Kelompok A dan kelompok B akan menghasilkan nilai tunggal berdasarkan tabel masing-masing kelompok atau grup. Selanjutnya akan dilakukan penjumlahan dari masing-masing nilai tersebut dengan skor aktivitas dan skor beban.

3) Langkah ke 3, Penentuan grand total dan respon tindakan.

Penggabungan total skor dari kelompoak A dan kelompok B untuk menghasilkan skor grand total. Nilai hasil penggabungan ini dijadikan sebagai panduan untuk menentukan prioritas pengamatan berikutnya. Pada grand total terdiri dari skor satu sampai dengan tujuh. Angka satu sampai dengan tujuh ini merupakan nilai berdasarkan perkiraan resiko cidera dalam melakukan aktivitas dengan pembebanan yang diterima muskuloskeletal.

\subsection{Nordic Body Map (NBM)}

Nordic body map atau disingkat sebagai NBM merupakan salah satu alat ukur dalam ilmu ergonomi. Hasil NBM menyajikan tingkat keluhan dari yang tidak sakit sampai yang terasa sangat sakit (Wilson \& Corlett, 1990), sehingga NBM ini dapat digunakan untuk mengetahui sumber penyebab dari rasa sakit yang dialami oleh seseorang atau pekerja.

\subsection{Model Kano}

Model Kano adalah suatu model yang bertujuan untuk mengkategorikan atribut-atribut dari produk maupun jasa berdasarkan seberapa baik produk tersebut mampu memuaskan kebutuhan pelanggan 
(Sauerwein, Bailom, Matzler, \& Hinterburger, 1996). Adapun atribut-atribut layanan dapat dikategorikan menjadi:

1. Must be atau basic needs

Jika kinerja dari atribut yang bersangkutan rendah, pelanggan menjadi tidak puas. Namun, kepuasan pelanggan tidak akan meningkat jauh di atas netral meskipun kinerja dari atribut tersebut tinggi.

2. One dimensional atau performance needs

Tingkat kepuasan berhubungan linier dengan kinerja atribut, seiring dengan meningkatnya kinerja atribut maka kepuasan pelanggan akan meningkat pula.

3. Atractive atau excitement needs

Tingkat kepuasan pelanggan akan meningkat sangat tinggi dengan meningkatnya kinerja atribut. Namun, penurunan kinerja atribut tidak akan menyebabkan penurunan tingkat kepuasan.

4. Indifferent

Pelanggan tidak peduli dengan adanya atribut yang ditawarkan sehingga ada atau tidaknya atribut tersebut tidak akan berpengaruh terhadap kenaikan atau penurunan tingkat kepuasan pelanggan.

5. Kategori Reverse

Jika atribut yang berada pada kategori ini muncul, maka artinya pelanggan akan merasa tidak puas. Namun sebaliknya, jka atribut tersebut tidak ada, maka akan muncul kepuasan pelanggan.

6. Kategori Questionable

Atribut kebutuhan yang berada pada kategori ini tidak dapat diterjemahkan dengan jelas karena terjadi kontradiksi antara jawaban pelanggan dengan pertanyaan yang saling berpasangan.

Penentuan kategori atribut untuk setiap responden dilakukan dengan melihat ketentuan pada tabel evaluasi kano yaitu pada Tabel 1.

Tabel 1. Evaluasi Kano

\begin{tabular}{|c|c|c|c|c|c|c|c|}
\hline \multirow{2}{*}{\multicolumn{3}{|c|}{ Need Customer }} & \multicolumn{5}{|c|}{ Disfungsional } \\
\hline & & & \multirow{2}{*}{$\begin{array}{c}\frac{1}{\text { Suka }} \\
\mathrm{Q}\end{array}$} & \multirow{2}{*}{ 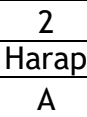 } & \multirow{2}{*}{ 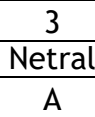 } & \multirow{2}{*}{$\begin{array}{c}4 \\
\text { Toleransi } \\
\text { A }\end{array}$} & \multirow{2}{*}{$\begin{array}{c}5 \\
\text { Tidak Suka } \\
0\end{array}$} \\
\hline \multirow{5}{*}{ Fungsional } & 1 & Suka & & & & & \\
\hline & 2 & Harap & $\mathrm{R}$ & I & I & I & $M$ \\
\hline & 3 & Netral & $\mathrm{R}$ & 1 & 1 & 1 & $M$ \\
\hline & 4 & Toleransi & $\mathrm{R}$ & I & I & I & $M$ \\
\hline & 5 & Tidak Suka & $\mathrm{R}$ & $\mathrm{R}$ & $\mathrm{R}$ & $\mathrm{R}$ & Q \\
\hline
\end{tabular}

\begin{tabular}{|c|c|c|}
\hline \multicolumn{3}{|r|}{$\begin{array}{l}\text { rwein et., } 19 \\
=\text { Attractive }\end{array}$} \\
\hline & $\begin{array}{l}\mathrm{A} \\
\mathrm{R}\end{array}$ & $\begin{array}{l}=\text { Attractive } \\
=\text { Reverse }\end{array}$ \\
\hline
\end{tabular}

Klasifikasi atribut model kano tersebut ditampilkan dalam gambar 1

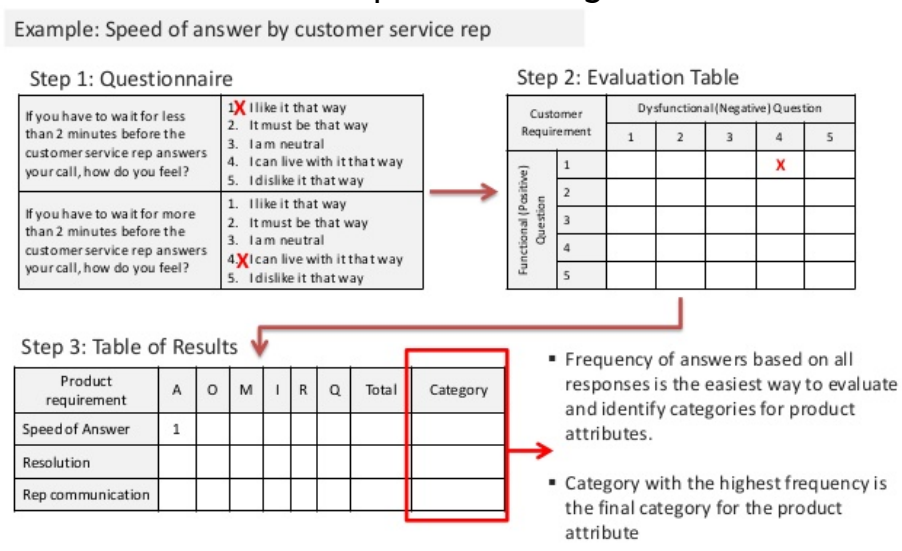

Sumber: Walden., 1993, Dalam Skripsi Putri P. D., 2015

Gambar 1. Proses Evaluasi Model Kano

Penentukan kategori kano tiap atribut dengan menggunakan Blauth's formula berdasarkan (walden,1993) sebagai berikut:

a. Jika jumlah nilai $O+A+M>I+R+Q$ maka dipilh nilai paling maksimum dari $O, A, M$.

b. Jika jumlah nilai $O+A+M<I+R+Q$ maka dipilh nilai paling maksimum dari $I, R, Q$.

c. Jika jumlah nilai $O+A+M=I+R+Q$ maka dipilh nilai paling maksimum dari $O, A, M, I, R, Q$.

Dari hasil tabel kemudian dievaluasi menggunakan koefisien kepuasan pelanggan yang dicari menggunakan Persamaan (1) dan (2): 
Extent of Satisfaction

$\frac{\mathrm{A}+\mathrm{O}}{\mathrm{A}+\mathrm{O}+\mathrm{M}+\mathrm{I}}$

$$
\begin{aligned}
& \text { Extent of Disatisfaction } \\
& =\frac{\mathrm{O}+\mathrm{M}}{-(\mathrm{A}+\mathrm{O}+\mathrm{M}+\mathrm{I})}
\end{aligned}
$$

Nilai untuk koefisien positif yaitu perkiraan dari 0 sampai dengan 1, jika semakin mendekati 1 semakin tinggi juga pengaruh terhadap kepuasan pelanggan dan nilai 0 menunjukan bahwa sedikit yang berpengaruh. Nilai untukkoefisien negatif mendekati -1 , dan jika 0 menandakan tidak mempengaruhi ketidakpuasan walaupun tidak terpenuhi.

\subsection{Quality Fucntion Deployment (QFD)}

Quality Function Deployment (QFD) yaitu pendekatan sistematik yang menentukan tuntutan customer needs dan kemudian menerjemahkannya secara akurat kedalam desain teknis, perencanaan produksi, dan manufaktur yang tepat untuk memungkinkan perusahaan dapat melebihi harapan pelanggan. Aktivitas pada metode QFD adalah sebagai berikut: (Wijaya,2011)

1. Identifikasi Customer needs pada atribut produk atau jasa melaui penelitian pada pelanggan.

2. Membuat matriks perencanaan (Planning Matrix)
a. Importance to Customer
b. Pengukuran Current satisfaction
e.Adjustment Factor
c. Nilai target (Goal)
f. Improvement Ratio)
d. K Value
g. Adjusted Improvement Ratio
h. Adjustment Importance

\subsection{House of Quality (HoQ)}

HOQ adalah sebuah struktur, ekspresi sistematis dari produk atau proses yang dilakukan oleh tim pengembang untuk memahami aspek-aspek pada keseluruhan proses perencanaan produk baru, pelayanan atau proses (Cohen, 1995). Bentuk umum dari setiap bagian matriks House of Quality ditampilkan dalam Gambar 2.

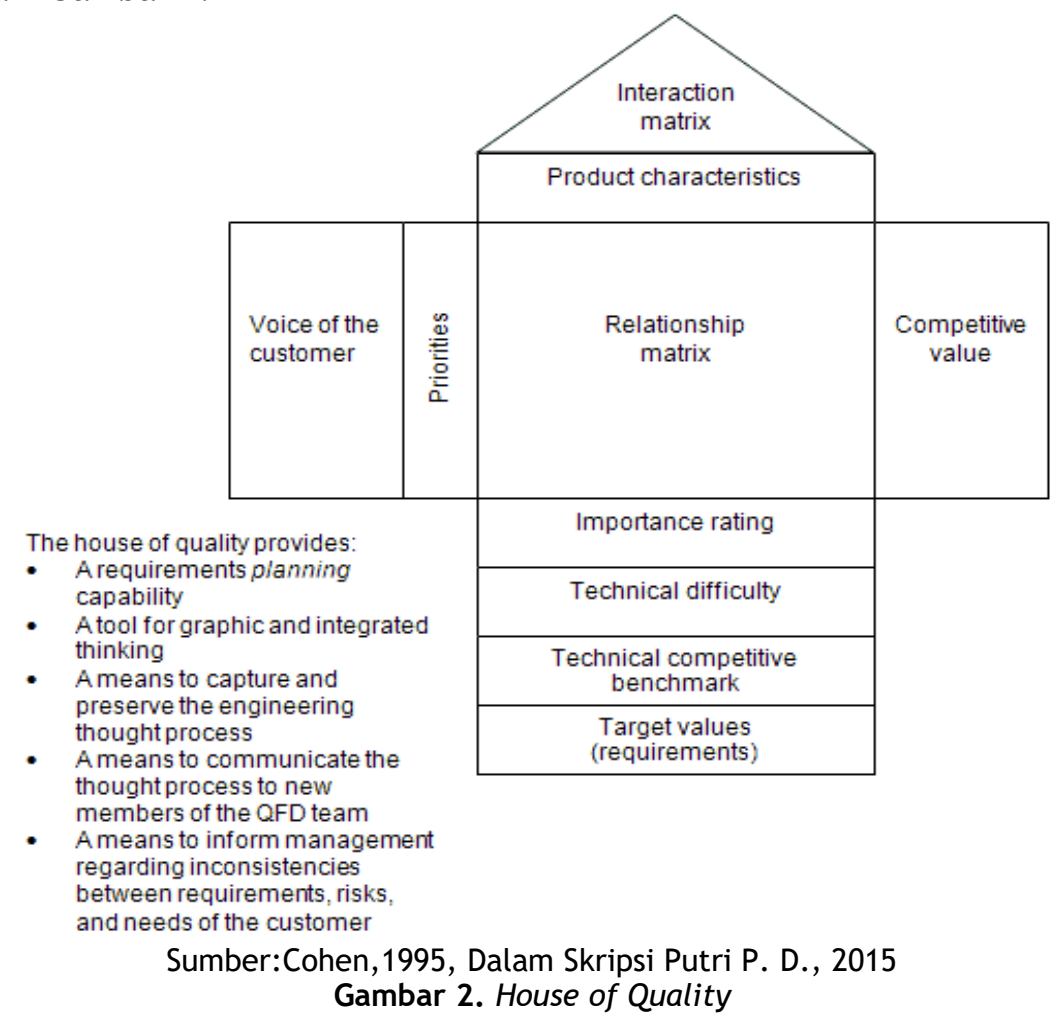

Dalam menggunakan matriks House of Quality harus melalui prosedur sebagai berikut:

1. Identifikasi keinginan konsumen ke dalam atribut-atribut produk

2. Penentuan tingkat kepentingan relatif dari atribut-atribut

3. Evaluasi atribut-atribut dari produk pesaing

4. Pembuatan matriks perlawanan antara atribut produk dengan karakteristik

5. Identifikasi hubungan antara karakteristik teknis dan atribut produk

6. Identifikasi interaksi yang relevan di antara karakteristik teknis 


\section{Penentuan gambaran target yang ingin dicapai untuk karakteristik teknis}

\subsection{Perancangan Produk}

Perancangan dan pengembangan produk dapat didefiniskan sebagai serangkaian aktifitas yang saling berkaitan yang dimulai dari analisis persepsi dan peluang pasar, sampai ke tahap produksi, penjualan serta pengiriman produk (Ulrich \& Eppinger, 2016). Ada tiga fungsi penting dalam proyek pengembangan produk, yaitu: pemasaran, perancangan dan manufaktur.

\section{Metodologi Penelitian}

Sebagai Langkah awal dalam penelitian ini dilakukan pengumpulan data awal berupa data postur tubuh pekerja, waktu pemasangan, kuesioner NBM, dan tools yang digunakan satt ini. Setelah semua data terkumpul, maka dilakukan penilaian postur kerja saat ini menggunakan metode RULA. Setelah diketahui hasil penilain postur tubuh maka dilakukan usaha perbaikan. Langkah selanjutnya ada memberikan suatu uslan perbaikan yang berkaitan dengan postur kerja, yaitu berupa usulan perancangan alat bantu untuk membentuk postur tubuh yang ergonomis.

Sebagai langkah awal dalam pembuatan alat bantu dilakukan penyebaran kuesioner untuk mendapatkan atribut yang digunakan. Kemudian atribut tersebut diseleksi menggunakan metode KANO untuk mengetahui atribut mana yang berpengaruh pada kepuasan pelanggan. Atribut yang sudah terseleksi akan digunakan dalam QFD dan tabel HoQ yang mana untuk menentukan spesifikasi pembuatan alat bantu. Hasil dari spesifikasi tersebut akan diaplikasikan dalam rancangan alat bantu dan dikombinasikan dengan ukuran antropometri area kerja berdiri dengan populasi orang Asia.

Setelah rancangan selesai, maka alat bantu tersebut akan dibuat dengan harga yang ditawarkan oleh supplier. Selanjutnya alat bantu akan diujicobakan pada pekerja untuk memasang nipple ke manifold block dan dilakukan evaluasi ulang terhadap postur tubuh setelah menggunakan alat bantu. Waktu pemasangan juga dihitung ulang apakah lebih cepat dari sebelumnya atau tidak dan yang terakhir adalah pembuatan work instruction untuk pemasangan nipple yang menggunakan alat bantu. Langkah-langkah penelitian dalam diagram alir yang ditunjukan pada Gambar 3.
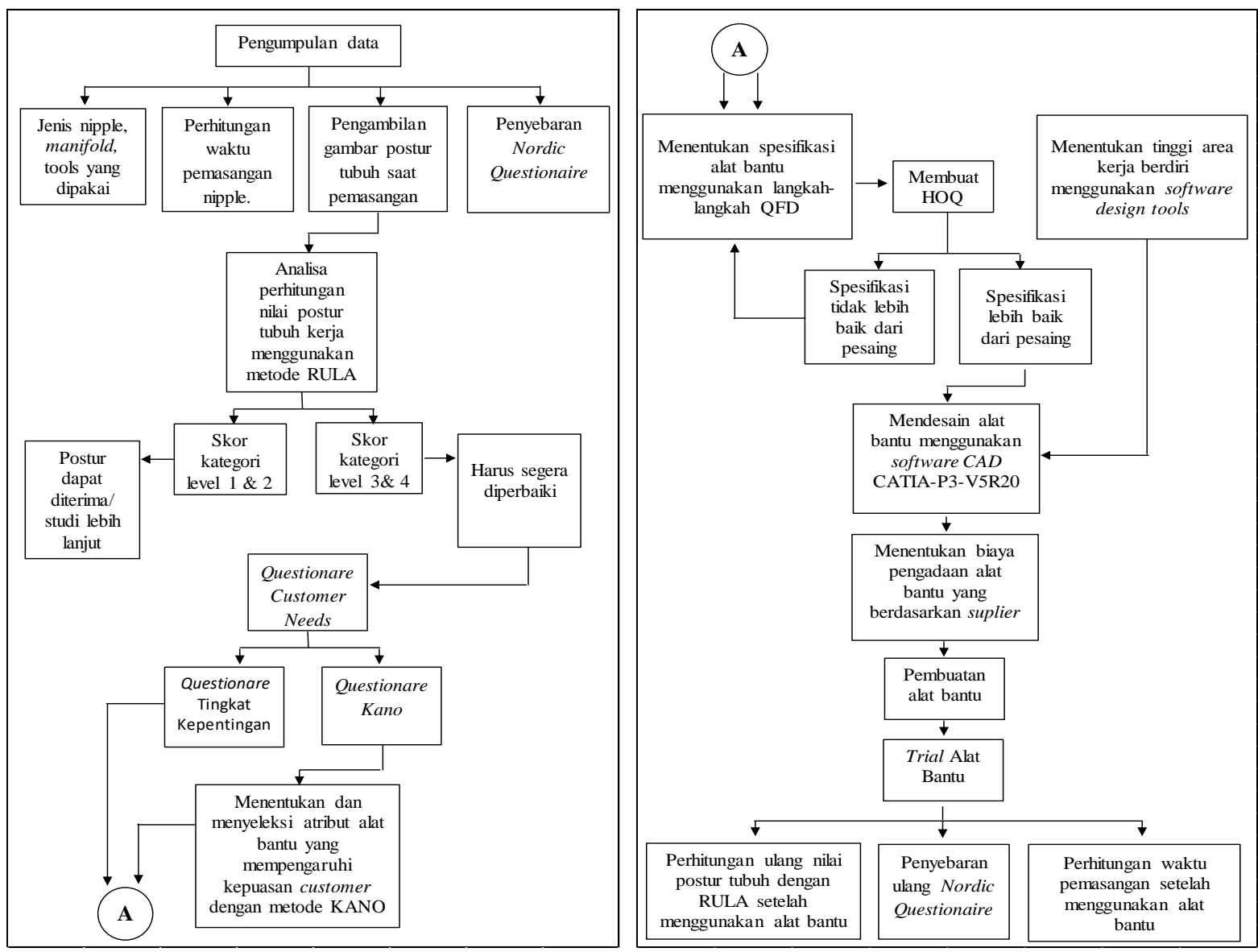
Gambar 3. Kerangka Penelitian

\section{Hasil dan Pembahasan}

\subsection{Tabulasi Standard Nordic Questionaire}

Tabel tarbulasi hasil kuesioner ditunjukan pada tabel 2 berdasarkan kuesioner nordic yang diberikan kepada 4 karyawan.

Tabel 2. Tabulasi Hasil Kuesioner Nordic

\begin{tabular}{|c|l|c|c|}
\hline No & \multicolumn{1}{|c|}{ Keluhan } & Jumlah & Presentase \\
\hline 1 & Leher bagian atas & 3 & $60 \%$ \\
\hline 2 & Bahu kiri & 5 & $100 \%$ \\
\hline 3 & Bahu kanan & 5 & $100 \%$ \\
\hline 4 & Pinggang & 5 & $100 \%$ \\
\hline 5 & Lengan atas kanan & 3 & $60 \%$ \\
\hline 6 & Tangan kanan & 2 & $40 \%$ \\
\hline 7 & Tangan Kiri & 2 & $40 \%$ \\
\hline 8 & lengan bawah kanan & 2 & $40 \%$ \\
\hline 9 & Pergelangan kaki kiri & 2 & $20 \%$ \\
\hline 10 & Pantat & & $40 \%$ \\
\hline
\end{tabular}

\subsection{Waktu Pemasangan Nipple ke Manifold}

Dalam perhitungan waktu proses pemasangan, type manifold dan nipple yang digunakan adalah yang paling sering dipakai. Data hasil perhitungan waktu pemasangan ditunjukan pada Tabel 3.

Tabel 3. Data Hasil Perhitungan Waktu Pemasangan

\begin{tabular}{|c|c|c|c|c|}
\hline No & Jenis Part & Qty (Pcs) & Waktu Pemasangan (min) & Rata-Rata(min) \\
\hline 1 & \multirow{12}{*}{$\begin{array}{c}\text { Block JX4021 } \\
\text { Nipple L PT1/4-PF 1/4 } \\
\text { (9TY10330404) } \\
\text { Nipple S PT1/4- PF 1/4 } \\
\text { (9TY10130404) } \\
\text { Plug PT 1/4 (9BPDB02000) }\end{array}$} & \multirow{5}{*}{$\begin{array}{l}1 \\
2\end{array}$} & 8.41 & \multirow{12}{*}{8.45} \\
\hline 2 & & & 8.14 & \\
\hline 3 & & & 8.12 & \\
\hline 4 & & & 8.09 & \\
\hline 5 & & & 9.35 & \\
\hline 6 & & \multirow{7}{*}{$\begin{array}{l}1 \\
1\end{array}$} & 9.07 & \\
\hline 7 & & & 8.01 & \\
\hline 8 & & & 9.25 & \\
\hline 9 & & & 8.06 & \\
\hline 10 & & & 8.36 & \\
\hline 11 & & & 8.12 & \\
\hline 12 & & & 8.38 & \\
\hline & & otal Waktu & 101.36 & \\
\hline
\end{tabular}

\subsection{Penilaian Postur Tubuh Kerja Karyawan Menggunakan Metode RULA}

Gambar 4 menunukkan penilai postur tubuh pekerja yang diambil dari sudut dari masing-masing posisi tubuh.

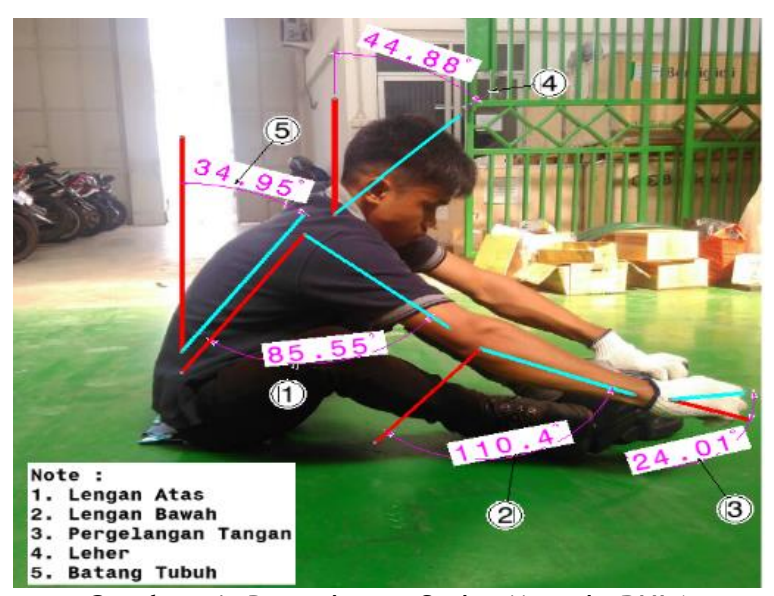

Gambar 4. Pengukuran Sudut Metode RULA 
Tabel 4 menampilkan hasil penilaian postur tubuh dari Gambar 4.

Tabel 4. Data Hasil Perhitungan Waktu Pemasangan

\begin{tabular}{|c|c|c|c|c|}
\hline No & Body Posture & Score & End Score & Grand Score \\
\hline 1 & Lengan atas mempunyai sudut $45^{0}-90^{\circ}$ & 3 & \multirow{4}{*}{4} & \multirow[t]{11}{*}{ - } \\
\hline 2 & Lengan bawah mempunyai sudut $>100^{\circ}$ & 2 & & \\
\hline 3 & Pergelangan tangan mempunyai sudut $>15^{0}$ & 3 & & \\
\hline 4 & Putaran pergelangan tangan berada digaris tengah & 1 & & \\
\hline 5 & Penambahan sakor aktivitas karena dilakukan berulang-ulang & 1 & \multirow{2}{*}{$\begin{array}{c}4+1+1=6 \\
\text { Grup A }\end{array}$} & \\
\hline 6 & Penambahan skor beban $2 \mathrm{~kg}-10 \mathrm{~kg}$ sesekali & 1 & & \\
\hline 7 & Leher mempunyai sudut $>20^{\circ}$ & 3 & \multirow{3}{*}{5} & \\
\hline 8 & Batang tubuh $20^{\circ}-60^{\circ}$ & 3 & & \\
\hline 9 & Kaki pada posisi tidak seimbang & 2 & & \\
\hline 10 & Penambahan sakor aktivitas karena dilakukan berulang-ulang & 1 & \multirow{2}{*}{$\begin{array}{c}5+1+1=4 \\
\text { Group B }\end{array}$} & \\
\hline 11 & Penambahan skor beban $2 \mathrm{~kg}-10 \mathrm{~kg}$ sesekali & 1 & & \\
\hline
\end{tabular}

\subsection{Customer Needs}

Sebagai langkah awal, dilakukan identifikasi kebutuhan customer dengan menyebarkan kuesioner kepada lima orang karyawan engineering yang sudah terbiasa dengan proses pemasangan. Hasil wawancara dirangkum dalam list customer needs yang diperlihatkan pada Tabel 5.

Tabel 5. Customer Needs

\begin{tabular}{|c|l|}
\hline No & \multicolumn{1}{c|}{ Customer needs } \\
\hline 1 & Alat bantu yang memungkinkan proses pengencanganya tidak cepat menguras tenaga \\
\hline 2 & Alat bantu yang dapat mempercepat proses pemasangan \\
\hline 3 & Alat bantu yang mempunyai bahan material yang kuat dan awet \\
\hline 4 & Alat yang memungkinkan proses pemasangan tidak pada posisi duduk \\
\hline 5 & Alat yang Mempermudah pemasangan nipple ke manifold \\
\hline 6 & Alat bantu yang memungkinkan proses pengencanganya tidak membuat tubuh pegal-pegal \\
\hline 7 & Biaya pengadaan alat bantu terjangkau \\
\hline 8 & Alat yang dapat dipakai/dipasangkan dengan ragum \\
\hline 9 & Alat yang dapat dipakai untuk mengencangkan semua tipe manifold \\
\hline 10 & Alat yang mempunyai lapisan tahan karat \\
\hline 11 & Alat yang dapat dipakai untuk memposisikan lebih dari satu manifold \\
\hline
\end{tabular}

\subsection{Evaluasi Kuesioner Menggunakanan Metode Kano}

Pada tahap ini akan dilakukan evaluasi terhadap atribut-atribut customer needs. Hasil dari kuesioner kano akan dievaluasi berdasakan tabel evaluasi kano yang mempunyai enam kategori yaitu:
$M=$ Must be
$0=$ One dimensional
$\mathrm{A}=$ Attractive
$\mathrm{Q}=$ Questionable
$\mathrm{R}=$ Reverse
$\mathrm{I}=$ Indefferent

Tabel evaluasi kano menghubungkan antara kategori fungsional dan disfungsional. Hasil dari tabel evaluasi Kano memperlihatkan setiap atribut customer needs kedalam 6 kategori kano. Hasil dari evaluasi tabel kano disajikan pada Tabel 6.

Tabel 6. Evaluasi Kuesioner Kano

\begin{tabular}{|c|c|c|c|c|c|c|c|c|c|c|}
\hline Atribut & M & $\mathbf{O}$ & $\mathbf{A}$ & $\mathbf{I}$ & $\mathbf{R}$ & $\mathbf{Q}$ & $\mathbf{A}+\mathbf{O}+\mathbf{M}$ & $\mathbf{I + R} \mathbf{Q}$ & Total & Kategori \\
\hline 1 & 2 & 3 & & & & & 5 & 0 & 5 & O \\
\hline 2 & 3 & 2 & & & & & 5 & 0 & 5 & M \\
\hline 3 & 3 & 1 & & 1 & & & 4 & 1 & 5 & M \\
\hline 4 & & 3 & 1 & 1 & & & 4 & 1 & 5 & 0 \\
\hline 5 & 1 & 2 & 1 & 1 & & & 4 & 1 & 5 & 0 \\
\hline 6 & 2 & 3 & & & & & 5 & 0 & 5 & 0 \\
\hline 7 & 2 & & & 3 & & & 2 & 3 & 5 & I \\
\hline 8 & 3 & 1 & & 1 & & & 4 & 1 & 5 & $M$ \\
\hline 9 & & & 3 & 2 & & & 3 & 2 & 5 & A \\
\hline 10 & 1 & & & 4 & & & 1 & 4 & 5 & I \\
\hline 11 & 3 & 1 & & 1 & & & 4 & 1 & 5 & $M$ \\
\hline
\end{tabular}


Berikut adalah contoh penentuan kategori dalam tabel 6 pada nomor 1 berdasarkan blauth's formula: Atribut nomor 1 menunjukan bahwa nilai $A+O+M=5>$ daripada nilai $I+R+Q=0$, maka yang kategori yang dipilih adalah nilai maksimum dari $\mathrm{A}, \mathrm{O}$ atau $M$ yaitu ketegori $\mathrm{O}$ dengan nilai sebesar 3 .

Pada tabel 6 yang masuk kedalam kategori attractive yaitu atribut nomor 9, atribut nomor 1, 4, 5, 6 masuk dalam kategori one dimensional, atribut nomor 7 dan 10 masuk ke dalam kategori indifferent, kemudian yang terakhir atribut nomor 2, 3, 8, dan 11 masuk ke dalam kategori must be. Atribut yang masuk ke dalam kategori indifferent yaitu nomor 7 dan 10. Kategori indifferent merupakan kategori yang netral yaitu tidak akan mempengaruhi kepuasan atau ketidakpuasan customer dengan adanya atribut tersebut. Selanjutnya untuk atribut selain nomor 7 dan 10 akan digunakan dalam analisis data berdasarkan metode Quality Function Development (QFD).

\subsection{Penggunaan Metode Quality Function Development (QFD)}

Setelah data atribut Customer needs dievaluasi menggunakan metode kano, langkah selanjutnya adalah menerjemahkan kebutuhan customer menjadi respon teknik yang sesuai dengan kebutuhan customer menggunakan metode QFD. Langkah yang dilakukan dalam QFD adalam membuat HoQ.

\subsubsection{Menghitung HOQ (House of Quality)}

a. Menentukan Respon Teknis

Langkah pertama dalam pembuatan House of Quality adalah menentukan respon-respon teknis. Respon teknis ditentukan berdasarkan customer needs yang telak diseleksi dalam metode kano. Respon teknis ditampilkan pada Tabel 7.

\begin{tabular}{|c|c|c|c|}
\hline No & Customer Needs & \multicolumn{2}{|r|}{ Spesifikasi Produk } \\
\hline 1 & $\begin{array}{l}\text { Alat bantu yang memungkinkan proses } \\
\text { pengencanganya tidak membuat tubuh } \\
\text { pegal-pegal }\end{array}$ & \multirow{5}{*}{ 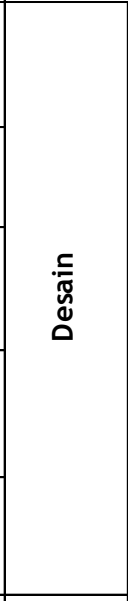 } & Postur kerja memiliki level resiko cidera yang minimum \\
\hline 2 & $\begin{array}{l}\text { Alat yang dapat dipakai untuk } \\
\text { mengencangkan semua tipe manifold }\end{array}$ & & $\begin{array}{l}\text { Desain jig dibuat mengikuti lubang baut semua tipe } \\
\text { manifold block dengan ukuran M6 }\end{array}$ \\
\hline 3 & $\begin{array}{c}\text { Alat bantu yang memungkinkan proses } \\
\text { pengencanganya tidak cepat menguras } \\
\text { tenaga }\end{array}$ & & $\begin{array}{c}\text { Proses kerjanya dipasangkan dengan meja kerja + } \\
\text { ragum + jig dengan tinggi mengikuti ukuran standar } \\
\text { antropometri orang asia }\end{array}$ \\
\hline 4 & $\begin{array}{l}\text { Alat yang dapat dipakai/dipasangkan } \\
\text { dengan ragum }\end{array}$ & & $\begin{array}{c}\text { Lebar jig yang berpasangan dengan ragum } 42 \mathrm{~mm} \text {, dan } \\
\text { terdapat stoper di jig supaya tidak jatuh ke bawah, } \\
\text { Panjangnya melebihi ragum } 215 \mathrm{~mm}\end{array}$ \\
\hline 5 & $\begin{array}{l}\text { Alat yang Mempermudah pemasangan } \\
\text { nipple ke manifold }\end{array}$ & & $\begin{array}{c}\text { Memakai baut M6 untuk memasang manifold ke jig, } \\
\text { dan posisi semua lubang manifold dapat dipasang nipple } \\
\text { dalam satu posisi }\end{array}$ \\
\hline 6 & $\begin{array}{c}\text { Alat yang memungkinkan proses } \\
\text { pemasangan tidak pada posisi duduk }\end{array}$ & \multirow{3}{*}{$\begin{array}{l}\overline{\tilde{n}} \\
\stackrel{\text { on }}{5} \\
\text { Ju }\end{array}$} & Fungsi alatnya digunakan dengan posisi berdiri \\
\hline 7 & $\begin{array}{l}\text { Alat bantu yang dapat mempercepat } \\
\text { proses pemasangan }\end{array}$ & & $\begin{array}{c}\text { Manifold diposisikan menghadap ke atas, fungsinya } \\
\text { supaya semua lubang manifold dapat langsung dipasang } \\
\text { nipple dengan lebar jignya } 53 \mathrm{~mm}\end{array}$ \\
\hline 8 & $\begin{array}{l}\text { Alat yang dapat dipakai untuk } \\
\text { memposisikan lebih dari satu manifold }\end{array}$ & & Dibuat dua sisi penempatan manifold (kanan dan kiri) \\
\hline 9 & $\begin{array}{l}\text { Alat bantu yang mempunyai bahan } \\
\text { material yang kuat dan awet }\end{array}$ & Material & $\begin{array}{l}\text { Menggunakan Material besi S45C (kadar carbon 0.42- } \\
0.5 \% \mathrm{C} \text { ) dengan HRC40 (Kekerasan rockwell scala C) }\end{array}$ \\
\hline
\end{tabular}

\section{b. Diagram House of Quality}

House of quality menjelaskan secara keseluruhan dari customer needs, spesifikasi product, hubungan antara customer needs dan spesifikasi, hubungan antar spesifikasi, benchmarking customer needs, dan benchmarking spesifikasi produk yang akan dibuat dengan produk yang sudah ada. Dalam hal ini juga ditampilkan importance scale dari customer, kemudian nilai target/goal dari perusahaan. Selain itu juga ditampilkan peringkat dari masing-masing spesifikasi. Untuk spesifikasi peringkat pertama adalah proses kerjanya dipasangkan dengan meja kerja + ragum + jig dengan tinggi mengikuti ukuran standar antropometri orang asia. Walaupun hal itu merupakan peringkat pertama dan harus ada pada alat bantu yang akan dibuat, tetapi bukan berarti yang lain tidak terlalu penting. Semua spesifikasi 
sebisa mungkin disajikan dalam alat bantu tersebut. Lebih jelasnya untuk house of quality ditampilkan pada Gambar 5.

\subsection{Detail Desain Alat Bantu}

Hasil dari penentuan kebutuhan pelanggan atau pengguna (customer needs) dan spesifikasi produk akan digunakan sebagai acuan perancangan alat bantu. Perancangan desain alat bantu akan mengacu pada Desain assembly dari alat bantu ditunjukan pada Gambar 6.

Berdasarkan ukuran yang diperoleh dari software design tools dengan total tinggi area kerja adalah $988 \mathrm{~mm}$ pada populasi orang Asia, berikut ukuran tinggi keseluruhan dari meja kerja ditambah ragum kemudian ditambah tebal jig JX bloknya yang ditampilkan pada Gambar 7.

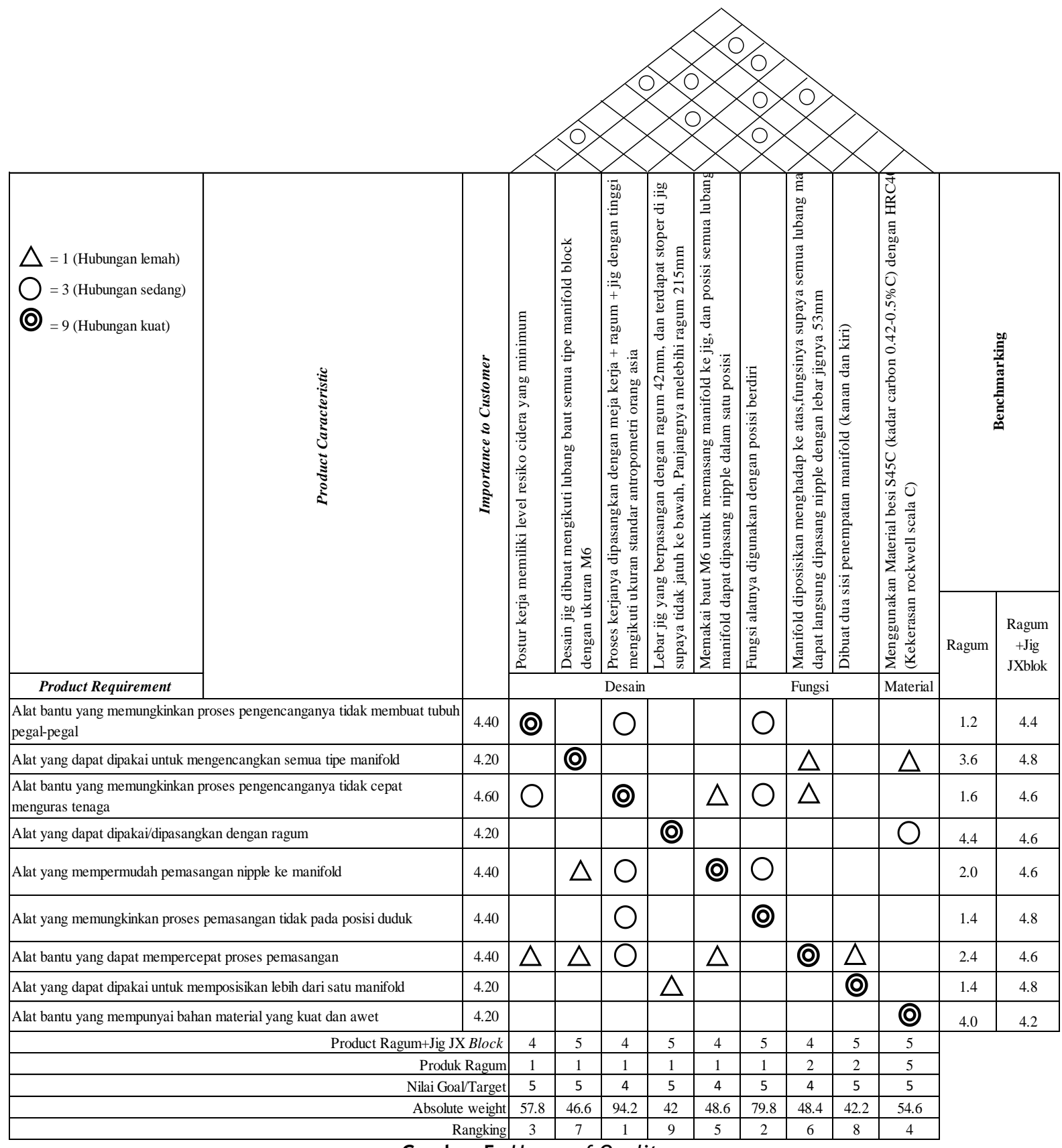

Gambar 5. House of Quality 


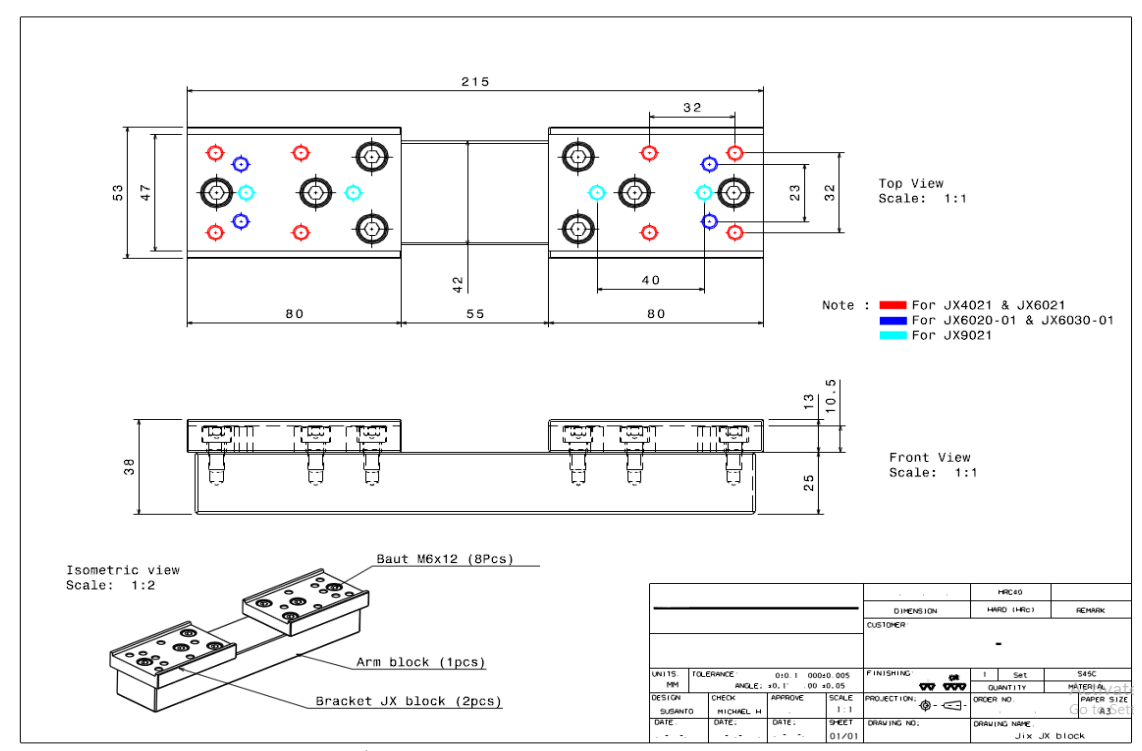

Gambar 6. Desain Assembly Jig JX Blok

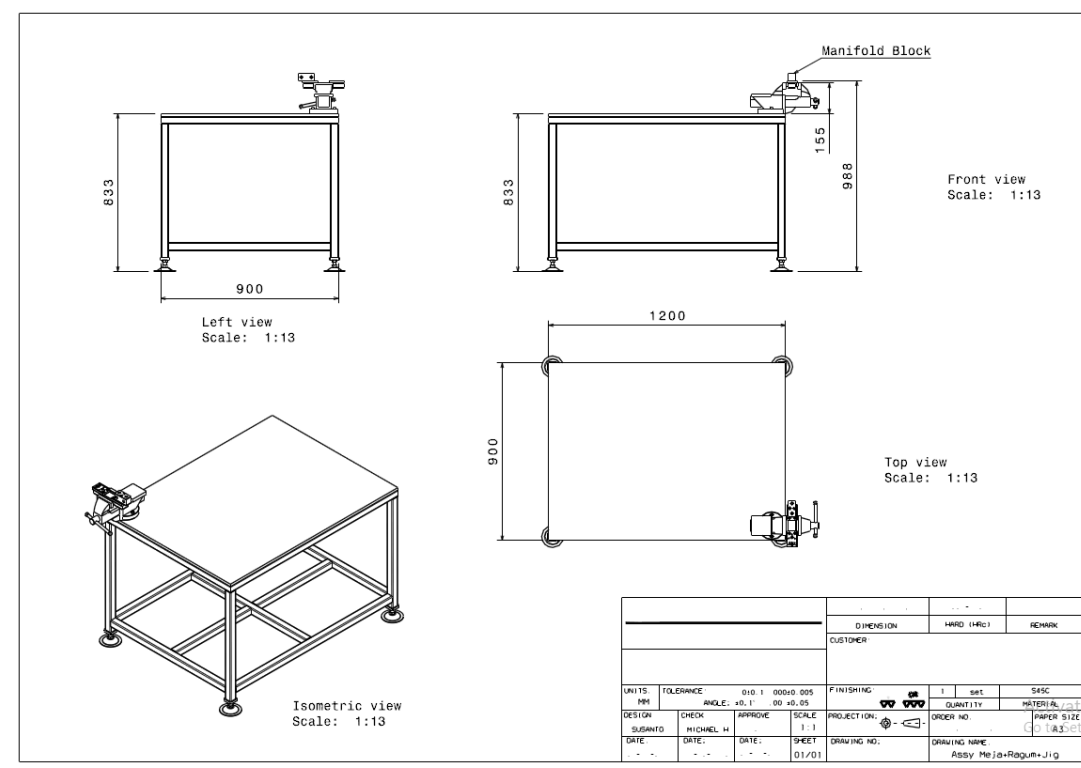

Gambar 7. Assembly Jig JX Blok + Meja Kerja + Ragum

\subsection{Evaluasi Postur Tubuh Setelah Perbaikan}

Langkah selanjutnya adalah membuat alat bantu yang telah dirancang pada proses sebelumnya. Alat bantu dibuat oleh pemasok dengan biaya sebesar Rp. 1.135.640, -. Sebelum alat bantu ini diimplementasikan, maka akan dilakukan diuji coba pada karyawan engineering PT. YAMATA MACHINERY untuk mengetahui postur tubuh kerja saat ini seperti yang terlihat pada Gambar 8. 


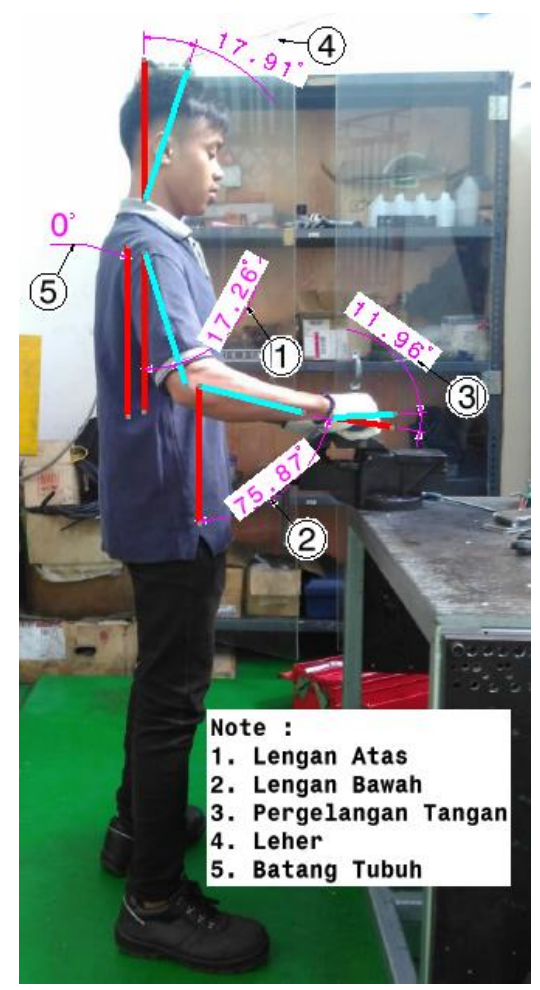

Gambar 8. Postur Tubuh Pekerja dengan Menggunakan Alat Bantu

Untuk mengevaluasi postur tubuh pekerja yang terlihat pada Gambar 8, digunakan RULA. Evaluasi dilakukan untuk mengetahui level resiko postur tubuh. Pada postur tubuh yang baru, karyawan mengerjakan proses pemasangan nipple ke manifold dengan posisi berdiri. Mengunakan meja yang digabungkan dengan ragum sekaligus jig JX block. Hasil evaluasi nilai resiko postur tubuh ditampilkan pada Tabel 8.

\begin{tabular}{|c|c|c|c|c|}
\hline No & Body Posture & Score & End Score & Grand Score \\
\hline 1 & Lengan atas mempunyai sudut $<20^{\circ}$ & 1 & \multirow{4}{*}{2} & \multirow{11}{*}{4} \\
\hline 2 & Lengan bawah mempunyai sudut $60^{\circ}-100^{\circ}$ & 1 & & \\
\hline 3 & Pergelangan tangan mempunyai sudut $0^{0}-15^{0}$ & 2 & & \\
\hline 4 & Putaran pergelangan tangan berada digaris tengah & 1 & & \\
\hline 5 & Penambahan sakor aktivitas karena dilakukan berulang-ulang & 1 & \multirow{2}{*}{$\begin{array}{c}2+1+1=4 \\
\text { Grup A }\end{array}$} & \\
\hline 6 & Penambahan skor beban $2 \mathrm{~kg}-10 \mathrm{~kg}$ sesekali & 1 & & \\
\hline 7 & Leher mempunyai sudut $10^{\circ}-20^{\circ}$ & 2 & \multirow{3}{*}{2} & \\
\hline 8 & Batang tubuh $0^{0}$ & 2 & & \\
\hline 9 & Kaki pada posisi seimbang & 1 & & \\
\hline 10 & Penambahan sakor aktivitas karena dilakukan berulang-ulang & 1 & \multirow{2}{*}{$\begin{array}{c}2+1+1=4 \\
\text { Group B }\end{array}$} & \\
\hline 11 & Penambahan skor beban $2 \mathrm{~kg}-10 \mathrm{~kg}$ sesekali & 1 & & \\
\hline
\end{tabular}

\subsection{Data Nordic Body Questionaire Setelah Perbaikan}

Berikut adalah kategori skala sakit dalam kuesioner yang diberikan.
1. Tidak sakit
2. Sedikit sakit
3.Sakit
4. Sangat sakit

Hasil dari kuesioner Nordic setelah perbaikan ditampilkan pada tabel 9.

Tabel 9. Evaluasi Nilai Resiko Postur Tubuh

\begin{tabular}{|c|l|l|c|c|c|}
\hline No & \multicolumn{1}{|c|}{ Nama } & $\begin{array}{c}\text { Jenis } \\
\text { Kelamin }\end{array}$ & Usia & Keluhan & Skala kategori sakit \\
\hline 1 & Han han & Laki-laki & 27 & Lengan bawah kanan & 2 \\
\hline 2 & Yohannes & Laki-laki & 23 & Lengan bawah kanan & 2 \\
\hline 3 & Teguh & Laki-laki & 25 & Lengan bawah kanan & 2 \\
\hline 4 & Indra & Laki-laki & 23 & Lengan bawah kanan & 2 \\
\hline 5 & Khamim & Laki-laki & 24 & Lengan bawah kanan & 2 \\
\hline
\end{tabular}


Tabel 9 menunjukkan bahwa hanya pada bagian lengan bawah kanan yang terasa sakit dengan kategori sakit yaitu 2 yang memiliki arti hanya sedikit sakit setelah melakukan proses pemasangan nipple ke 12 manifold block.

\subsection{Waktu Proses Pemasangan Setelah Perbaikan}

Total Waktu sebelum perbaikan untuk pemasangan 12 Block Manifold Sebesar 101,36 menit dengan rata-rata 8.45menit dan setelah perbaikan sebesar 28.18 menit dengan rata-rata 2,35 menit atau terjadi penurunan waktu pemasangan sebesar $73 \%$.

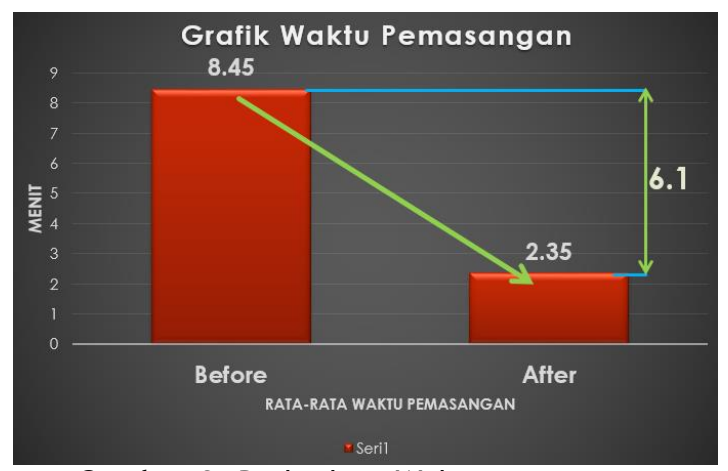

Gambar 9. Perbedaan Waktu pemasangan

\subsection{Work Instruction Proses Pemasangan}

Untuk menghindari terjadinya kesalahan pada proses pemasangan, maka dibutuhkan suatu urutan kerja, posisi pemasangan, dan alat apa saja yang digunakan. Proses tersebut ditampilkan dalam suatu form yang dinamakan work instruction. Form ini digunakan sebagai panduan yang menjelaskan kegiatan atau proses pemasangan nipple ke manifold block dari awal sampai akhir. Work Instruction pemasangan nipple ke manifold block ditampilkan pada Gambar 10.

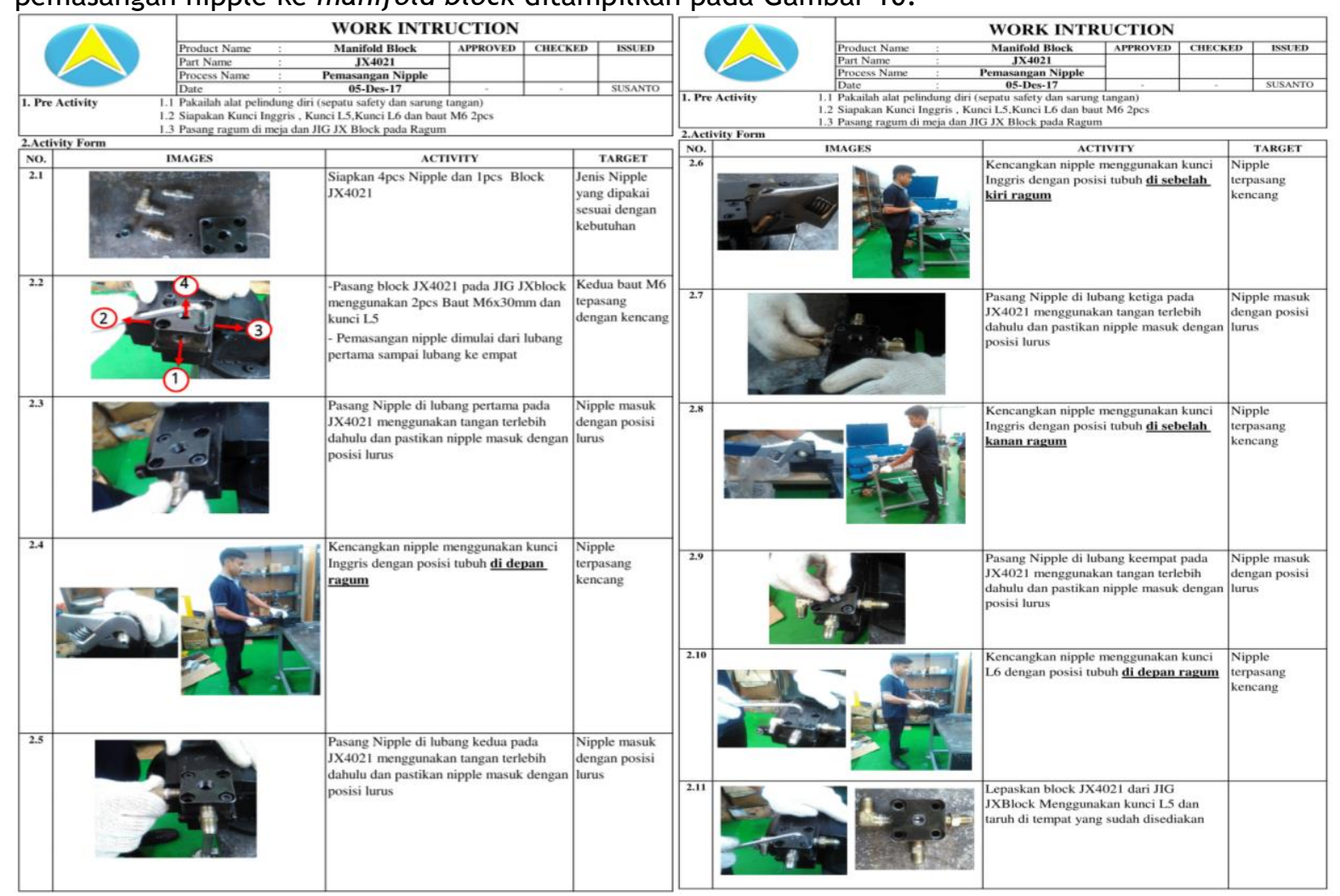

Gambar 10. Work Instruction 


\section{Kesimpulan}

Berdasarkan dari langakah-langkah yang sudah ditempuh, mulai dari penentuan masalah sampai dengan alanisa perbaikan. Didapatkan beberapa kesimpulan dari penelitian tersebut. Kesimpulan yang didapatkan sebagai berikut:

1. Berdasarkan pengukuran postur tubuh menggunakan metode RULA, didapatkan skor akhir untuk postur tubuh proses pemasangan nipple ke manifold adalah sebesar 7 poin. Hal ini berarti postur tubuh tersebut harus segera diperbaiki. Jadi penyebab terjadinya rasa sakit yang dialami oleh karyawan dalam proses tersebut adalah postur tubuh yang tidak sesuai dengan prinsip-prinsip ergonomi.

2. Berangkat dari masalah tersebut, solusi yang dilakukan adalah dengan pembuatan alat bantu untuk menciptakan postur tubuh dalam posisi yang benar berdasarkan prinsip-prinsip ergonomi. Pembuatan alat tersebut adalah Jig JX Block yang dikombinasikan dengan meja dan ragum mempermudah dan mempercepat proses pemasangan nipple ke manifold block sesuai dengan kebutuhan karyawan. Sebelumnya posisi kerja karyawan adalah duduk membungkuk dengan skor penilaian RULA sebesar 7, dengan menggunakan alat bantu postur kerja berubah menjadi berdiri dengan skor RULA sebesar 4. Dampak lainya adalah berkurangnya waktu proses dari yang sebelumnya untuk 12 set manifold sebesar 101,36 menit menjadi 28,18 menit.

\section{Daftar}

1. Cohen, L. (1995). Quality Function Deployment: How to Make QFD Work for You. Addison-Wesley

2. Leuder, R., (1996). A Purposed RULA for Computer User, Humanic ErgoSystem Inc, San Fransico

3. McAtamney, L. \& Corlett, E.N., (1993), RULA: A survey method for the investigation of workrelated upper limb disorders, Applied Ergonomics, 24: 91- 99. 10.

4. McAtamney, L. \& Corlett, E.N., (2004). Rapid Upper Limb Assessment (RULA) In Stanton, N. Et al. (eds.) Handbook of Human Factors and Ergonomics Method, Chapter 7, Boca Raton, FL, pp. 7: 1- 7:11 11.

5. Sauerwein E., Bailom F., Matzler K., Hinterburger H., (1996). The Kano Model: How to delight your customers. Preprints Volume I of the IX. International Working Seminar on Production Economics, Innsbruck/Igls/Austria, 313 -327.

6. Ulrich, K.D., Eppinger, S.D., (2016). Product Design and Development. $6^{\text {th }}$ Ed. McGraw-Hill Education, New York.

7. Wijaya, T. (2011). Manajemen kualitas jasa: Desain Serqual, QFD dan Kano, PT. Index, Yogyakarta,.

8. Wilson, J.R, Corlett, E.N., (1990). Evaluation of Human Work a Practical Ergonomics Methodology, Tailor \& Francis, London. 